\title{
EFFECTIVE SPEND MANAGEMENT THROUGH ELECTRONIC REVERSE AUCTION CONFIGURATIONS
}

DOI: 10.12776/QIP.V17I1.151

\author{
MOJMÍR PRÍDAVOK, RADOSLAV DELINA
}

\section{INTRODUCTION}

Information and Communication Technologies (ICT) are perceived as a catalyst for economic growth. Number of studies, carried out by world- and Europeanleading institutions such as Organisation for Economic Co-operation and Development (OECD) or European Commission, addresses this issue in their reports. (OECD, 2004), studies the influence and measures the impact of ICT on firms. The development of clear ICT-focused economic policies was the main objection of the report published in 2010 on demand of European Commission's project (Reenen, et al., 2010). The ICT contributes to the economic growth through enabling the production of more goods in shorter time by facilitating computerized systems (Bongo, 2005), (Miles, 2002). In order to understand the impact of the ICT on economic growth several indexes, measuring the progress of ICT adoption in each country, were introduced. Most famous are Networked Readiness Index (NRI) regarding the technological field and Global Competitiveness Index (GCI) and World Competitiveness Index (WCI) in the economic field. Several studies have already identified dependencies between the standard economic indexes and the above mentioned ICT-related indexes (Sabol, et al., 2006).

At present, Business-to-Consumer (B2C) solutions get the most attention due to all the marketing activities these solutions are exposed to. However, according to the recent survey carried out by Oracle (2012) on the U.S. census data, Businessto-Business (B2B) transactions were responsible for almost 300 billion dollars trade in comparison to B2C's 200 billion dollars, making B2B revenue by $50 \%$ higher than B2C. Multiple business transactions form a network in which interorganizational communication and collaboration is more effective. 


\section{ELECTRONIC REVERSE AUCTIONS}

After several years of B2B solutions uptake, the form of e-sourcing or negotiation within global supply chain was considered as one of the most important factors for efficient collaboration between companies (Amelinckx et al., 2008). Very intensive research was done in the field of electronic reverse auction adoption and effective management (Smart \& Harrison, 2003), (Sudzina, et al., 2010). Electronic reverse auctions (eRA) provide not just huge potential savings or Total Cost of Ownership (TCO) reduction, but also improvements in quality and cycle time are expected. eRA represents an electronic sourcing method that builds a competitive and dynamic environment in which a number of suppliers compete against each other in real-time to win the business (Amelinckx, et al., 2008). Suppliers compete by bidding against each other through online software. Theory assumes that eRA represents pure market environment with information perfectly distributed between both buyers and suppliers (Amelinckx, et al., 2008).

Although, eRA usage was significantly increased during the last few years, the way how to achieve higher quality of e-procurement settings is still open. Moreover, such an increase in the eRA adoption was influenced by enormous marketing campaigns and it contributed to the e-bubble burst in 2000 as a result of unreasonable investments to IT. Due to such an extensive usage of eRA, great amount of procurement data exists, however very little research has been done yet. The higher quality in eRA settings management, the higher efficiency and effectiveness of whole procurement process.

New strategies and more complex eRA configuration call for next researchers to find optimal negotiation strategies within the procurement process. Very few studies were performed on real business data. Laboratory experiments that may lack business validity and case studies and interviews are often preferred. Number of bidders invited to the eRA, as an indicator of competitiveness of the environment, appears to be crucial. According to the laboratory experiment, higher number of bidders led to the lower final bids than it was in case of smaller number of bidders (Carter \& Stevens, 2007). Although, the impact of the eRA configuration (e.g. visibility, auction mechanisms) on the outcome of the eRA is indisputable, it is not straightforward. Empirical study based on 100 German companies revealed eRA configuration is used either very little or with a different intention than it was designed by. The example of such a configuration is the utilization of combinatorial auctions (only 15\%) or the utilization of multiattribute auctions that are used in $48 \%$, however not for the quality parameters evaluation, but for different price parameters (Eichstadt, 2008). For the achieving higher quality in eRA setting and whole e-procurement process, several parameters and portfolio of their settings have to be analysed in more details. In 2006, SAP provided a set of best practices based on their clients'experience (SAP, 2006). eRA parameterization through theoretical concepts was analyzed and visibility rules applicability based on the market conditions was discussed (Kumar \& Chang, 2007). Monetary value, suppliers' opportunity perception as 
well as lotting strategies and their implication on the success of the eRA, were topics discussed through case studies and depth interviews with eRA providers and buying organizations in 2001 (Carter, et al., 2004).

Summarizing these studies, the following hypotheses are introduced (Table 1):

Table 1 - Research hypotheses

\begin{tabular}{ll}
\hline Title & \multicolumn{1}{c}{ Statement } \\
\hline Hypothesis 1 & $\begin{array}{l}\text { There is a positive relationship between the number of bidders in } \\
\text { the eRA and its success. }\end{array}$ \\
\hline Hypothesis 2 & $\begin{array}{l}\text { There is a positive relationship between the monetary value in the } \\
\text { whole eRA and its success. }\end{array}$ \\
\hline Hypothesis 3 & $\begin{array}{l}\text { There is a positive relationship between the complexity of the eRA } \\
\text { configuration and its success. }\end{array}$ \\
\hline
\end{tabular}

\section{METHODOLOGY}

\subsection{Research approach}

In order to study the proposed hypotheses, procurement data of 9 public companies in Slovakia has been analyzed. Data gathering was performed between 2007 and 2011 through electronic reverse auction system as a preferred tool used for the procurement of products and services in these companies. During this period total of 18,633 products and services, grouped in 560 auction cases, were procured and more than 8.4 million euro was spent.

The parameters presented in the Table 2 were analyzed and tested.

Table 2 - Summary of the crucial eRA parameters

\begin{tabular}{lll}
\hline Parameter & Abbreviation & Description \\
\hline $\begin{array}{l}\text { Monetary Value } \\
\text { of a given } \\
\text { Auction }\end{array}$ & MVA & $\begin{array}{l}\text { It is a total value of a contract that all the } \\
\text { bidders compete for in a given auction. }\end{array}$ \\
$\begin{array}{l}\text { Total Savings in a } \\
\text { given Auction (in } \\
\%)\end{array}$ & TSA & $\begin{array}{l}\text { It is a difference between the highest and the } \\
\text { lowest bid in a given auction. }\end{array}$ \\
$\begin{array}{l}\text { Total Savings (in } \\
\%)\end{array}$ & TS & $\begin{array}{l}\text { It is a difference between the lowest price of a } \\
\text { given item procured in the past and the lowest } \\
\text { bid in the current auction. }\end{array}$
\end{tabular}




\begin{tabular}{|c|c|c|}
\hline $\begin{array}{l}\text { Auction } \\
\text { Complexity } \\
\text { Indicator }\end{array}$ & $\mathrm{ACI}$ & $\begin{array}{l}\text { It indicates to what extent the auction } \\
\text { configuration is used by a procurer. It contains } \\
11 \text { parameters with the Boolean value, either } \\
\text { the parameter was set (true) or not (false). The } \\
\text { value ranges from } 0 \text { (none of the parameters } \\
\text { was set) to } 11 \text { (all the parameters were set). }\end{array}$ \\
\hline $\begin{array}{l}\text { Number of } \\
\text { Bidders } \\
\text { Competing }\end{array}$ & NBC & $\begin{array}{l}\text { It is a number of bidders that actively } \\
\text { participated in a competitive round by } \\
\text { submitting at least one bid. }\end{array}$ \\
\hline $\begin{array}{l}\text { Number of } \\
\text { Bidders Invited }\end{array}$ & NBI & $\begin{array}{l}\text { It is a number of bidders that procurer decided } \\
\text { to invite to a given auction. Note that, they } \\
\text { could be invited but they did not have to } \\
\text { participate in a competitive round by } \\
\text { submitting their bid. }\end{array}$ \\
\hline
\end{tabular}

\subsection{Data analysis and results}

In the first step, it was tested whether the selected data fits a normal distribution or not. For this purpose, the Kolmogorov-Smirnov test of normality was performed. The data is considered normally distributed if the Sig. value is greater than 0.05 . The results, in the Table 3 , show that none of the variables fit a normal distribution (the Sig value for each parameter is equal to 0.00).

Table 3 - Kolmogorov-Smirnov test of normality

\begin{tabular}{llll}
\hline & Statistic & df & Sig. \\
\hline MVA & 0.28 & 18633 & 0.00 \\
TSA & 0.10 & 18633 & 0.00 \\
TS & 0.47 & 18633 & 0.00 \\
ACI & 0.32 & 18633 & 0.00 \\
NBC & 0.24 & 18633 & 0.00 \\
NBI & 0.34 & 18633 & 0.00 \\
\hline
\end{tabular}

In the second step, correlations were calculated to determine the strength of the associations among the pairs of the selected variables. The most commonly used bivariate correlation test is the Pearson correlation test. One of the prerequisites of this test is that variables must be approximately normally distributed. According to the results of the test of normality (Table 3), none of the parameters can be assumed to be normally distributed and thus Spearman correlation test, that does not assume normal distribution of data, is used. The correlation matrix is presented in the Table 4. 
Table 4 - Correlation matrix: Spearman Correlation Test

\begin{tabular}{lllllll}
\hline & MVA & TSA & TS & ACI & NBC & NBI \\
\hline MVA & - & 0.06 & 0.13 & -0.72 & 0.18 & 0.12 \\
TSA & 0.06 & - & 0.08 & -0.09 & 0.38 & 0.13 \\
TS & 0.13 & 0.08 & - & -0.11 & 0.05 & 0.04 \\
ACI & -0.72 & -0.09 & -0.11 & - & -0.19 & -0.09 \\
NBC & 0.18 & 0.38 & 0.05 & -0.19 & - & 0.61 \\
NBI & 0.12 & 0.13 & 0.04 & -0.09 & 0.61 & -
\end{tabular}

All the results in the Table 4 are statistically significant due to the fact that the pvalue for every correlation coefficient is lower than 0.05 .

\section{FINDINGS}

Hypothesis 1 predicted that there is a positive relationship between the number of bidders in the eRA and its success. Results shown in Table 4 favour this hypothesis. Spearman's Correlation Coefficient $r=0.38$ shows a medium correlation between the NBC and TSA. Simply said, the more bidders participate the higher savings could be expected. This result is no surprise. On the contrary, it is in line with the majority of economic theories and experimental researches that were conducted in this field (Amelinckx, et al., 2008), (Carter \& Stevens, 2007), (SAP, 2006).

Hypothesis 2 predicted a positive relationship between the monetary value in the eRA and its success. In order to evaluate this hypothesis, MVA parameter and its impact on either TSA or TS had to be considered and tested. The value of the Spearman's Correlation Coefficient $r=0.06$ in case of MVA-TSA and $r=0.13$ in case of MVA-TS means no correlation or very small correlation respectively. While the result of the first hypothesis was not a surprise, in this case it was not expected that the monetary value would not have any impact on the success of the eRA. Economic theory expected and experimental researches proved that bidders use to prepare and compete for higher contracts more. As a consequence of such a bidding war, higher savings are expected (Carter, et al., 2004).

What is even more interesting is the result of the Hypothesis 3. It predicted that there is a positive relationship between the complexity of the eRA configuration and its success. Complexity of the eRA configuration is expressed through the Auction Complexity Indicator (ACI), see the Table 2 for the explanation. For the purpose of this hypothesis ACI's impact on either the TSA or TS had to be tested. The value of the Spearman's Correlation Coefficient $r=-0.09$ in case of ACI-TSA and $r=-0.11$ in case of ACI-TS means no correlation or very small negative correlation respectively. There could be several reasons behind such results. Since the theory is pretty straightforward and uniform in stressing the benefits of various eRA configurations, the most probable reason seems to be the 
lack of knowledge of the people that set the parameters and configure the whole auction process (Carter, et al., 2004), (Eichstadt, 2008), (Kumar \& Chang, 2007).

Looking at the rest of the correlation coefficients at the correlation matrix (Table 4) two coefficients are very high and thus they are worth to discuss. Strong correlation between NBI and NBC is caused by the similarity between the parameters. It is obvious that the higher number of invited suppliers to the eRA results in the higher number of bidders in a competitive round. Thus the correlation coefficient $\mathrm{r}=0.61$ cannot be considered relevant. However, particularly interesting is the second coefficient showing very strong negative relationship between the ACI and MVA. The value of the Spearman's Correlation Coefficient $r=-0.72$. This result brings an interesting look at the eRA configuration with regards to the monetary value of the auction. The higher the monetary value of the auction is, the less parameters are utilized while setting the eRA up.

\section{CONCLUSION}

The rapid adoption of eRA has undoubtedly contributed to the higher efficiency in procurement processes and built foundations for initial business network analysis (Janke, 2011). However, the further TCO reductions resulting from the understanding of eRA strategies and configurations remain to be blurred. In this paper several eRA parameters has been analyzed to identify determinants of quality procurement settings. Analysis has been performed on real business data and thus these results should be considered as an extension of economic theory and laboratory experiments carried out in this field.

\section{REFERENCES}

Amelinckx I., Muylle S., Lievens A. 2008. Extending electronic sourcing theory: An exploratory study of electronic reverse auction outcomes. Journal of Electronic Commerce Research and Applications, Vol. 7 No. 1, pp. 119-133.

Bongo P., 2005. The Impact of ICT on Economic Growth, Development and Comp Systems [online] EconWPA. Available at: < http://128.118.178.162/eps/dev/papers/0501/0501008.pdf > [Accessed 15 July 2012].

Carter C. R., et al. 2004. Reverse auctions: Grounded theory from the buyer and supplier perspective, Transportation Research, Vol. 40 No. 3, pp. 229-254.

Carter C. R., Stevens C. K. 2007. Electronic reverse auction configuration and its impact on buyer price and supplier perceptions of opportunism: a laboratory experiment, Journal of Operations Management, Vol. 25 No. 5, pp. 1035-1054.

Eichstadt T. 2008. Applying Auction Theory to Procurement Auctions - An Empirical Study Among German Corporations, in Gimpel H. et al. Negotiation, 
Auctions, and Market Engineering, Springer-Verlag Berlin Heidelberg, Berlin (DE), pp. 58-67.

Janke F. 2011. The Use Of Hidden Data in Electronic Business Networks: Benchmark and Network Performance Indicators, in Proceedings of The $19^{\text {th }}$ Interdisciplinarity Information Management Talks, Jindrichuv Hradec, Czech Republic, 12-14 September, pp. 341-348.

Kumar S., Chang C. 2007. Reverse auctions: How much total supply chain cost savings are there? - A conceptual overview, Journal of Revenue \& Pricing Management, Vol. 6 No. 3, pp. 229-240.

Miles P. 2002. Globalisation - Economic Growth and Development and Development Indicators, Planet Papers, [online] Available at: <http://www.planetpapers.com/Assets/4302.php> [Accessed 15 July 2012].

OECD Publication Service, 2004. The Economic Impact of ICT. Measurement, Evidence and Implications. [pdf] Paris: Publication Service. Available at: 〈http://browse.oecdbookshop.org/oecd/pdfs/free/9204051e.pdf> [Accessed 15 July 2012]

Oracle World Headquarters, 2012. B2B E-Commerce Survey: Results and Trends". [pdf] Redwood Shores: Oracle Corporation. Available at: $<\mathrm{http} / /$ www.oracle.com/us/products/applications/b2b-ecommerce-trends-20121503041.pdf> [Accessed 11 September 2012]

Reenen J.V., et al. 2010. The Economic of ICT. Center for Economic Performance. Center for Economic Performance. [pdf] Available at: $<$ http://ec.europa.eu/information_society/eeurope/i2010/docs/eda/econ_impact_o f_ict.pdf> [Accessed 15 July 2012].

Sabol T., et al. 2006. Indexes of economic, social and technological development, Ekonomický časopis, Vol. 54, no. 7, pp. 685-698.

SAP White Paper, 2006. Reverse Auction Best Practices: Practical Approaches to Ensure Successful Electronic Reverse Auction Events". [pdf] SAP AG. Available at: <http://www.sdn.sap.com/irj/scn/index?rid=/library/uuid/b018b90ab9e5-2910-c6bd-f8f7bc3a34a9> [Accessed 3 July 2012].

Smart A., Harrison A. 2003. Online reverse auctions and their role in buyersupplier relationships, Journal of Purchasing and Supply Management, Vol. 9, No. 5-6, pp. 257-268.

Sudzina F., et al. 2010. Impact of ERP systems implementation: A case of Slovak companies, in Proceedings of The $19^{\text {th }}$ Interdisciplinarity Information Management Talks, Jindrichuv Hradec, Czech Republic,. 8-10 September, pp. 65-73. 


\section{ABOUT THE AUTHOR}

Ing. Mojmír Prídavok, Ph.D. student, Technical University of Košice, Faculty of Economics, Department of Banking and Investments, Němcovej 32, 040 01, Košice, Slovakia, e-mail: mojmir.pridavok@tuke.sk.

doc. Ing. Radoslav Delina, Ph.D., Assistant Professor, Technical University of Košice, Faculty of Economics, Department of Banking and Investments, Nemcovej 32, 040 01, Košice, Slovakia, e-mail: radoslav.delina@ tuke.sk. 